\title{
Interprofessional education in Brazil: building synergic networks of educational and healthcare processes
}

\section{Introduction}

The health care practices supported by interprofessional education (IPE) and the debate about those processes are in the early stages in Brazil'. This does not mean that the country lacks a richness of previous experiences that are a fertile basis for expanding and strengthening IPE, being its conceptual framework and operational proposal very much in line with the cornerstones of the Brazilian Unified Health System (SUS) ${ }^{2}$. The SUS is the national public policy in health matters and is geared towards universal access, comprehensiveness and social participation, articulated around Primary Health Care as the backbone of the network ${ }^{3}$. In this editorial we outline social and political processes that have contributed to the development of interprofessional practice (IPP) in Brazil. We also describe an international colloquium which provided an important forum for discussion and debate around interprofessional education and collaboration. Based on discussions during this colloquium we go on to describe the establishment of a national collaborative network in interprofessional education and practice.

This editorial also marks a collaborative venture by the editors of Journal of Interprofessional Care and Interface - Comunicação, Saúde, Educação to work together and publish matched editorials in both English and Portuguese that explore key issues of mutual interest to readers of both journals.

\section{Brazilian context}

The social and political process that resulted in the building of such universal health care system ${ }^{4}$, was anchored in the aforementioned principles and resulted in acknowledging the need of interprofessional and interdisciplinary teamwork, especially in primary care and health care networks contexts. These circumstances fostered the uprising of innovative proposals for developments in teamwork practices, centered in health needs both of individuals and communities. Studies of initiatives in primary care, in mental health and hospitals (among other settings) that show, "success in reorganizing the modus operandi of teams, based in a technical care model that fosters interprofessional collaboration" 5 (p. 254). Not withstanding those successful stories, teamwork in Brazil still has a long road ahead to be consolidated as an effective practice and to overcome the usual fragmented work process, if we take as a reference the framework of collaborative interprofessional practice proposed as a global goal by the World Health Organization 6 .

This promising context and subsequently the need of strengthening the public policies for a reorientation of health professional training were the starting point for summoning a first International Colloquium of Interprofessional Education and Practice, in Natal (Rio Grande do Norte state, in the Northeast region of Brazil) on July $12^{\text {th }}$ and $13^{\text {th }}, 2015$.

\section{An international colloquium}

The Colloquium was organized by the Federal University of Rio Grande do Norte (UFRN), the State University of Rio Grande do Norte (UERN), the Secretariat for Labor and Education of the Ministry of Health (SGTES) and the 
Pan American Health Organization (PAHO). The following academic institutions were key participants in the organization: Botucatu School of Medicine (FMB), as part of the State University of Sao Paulo (Unesp), the Federal University of Sao Paulo (Unifesp), the University of Sao Paulo (USP) and the Federal University of Minas Gerais (UFMG), with the support of several special projects called Pro-Ensino financed by the federal Coordination of High Level Education Improvement (Capes), a branch of the Ministry of Education. The participants came from several states and universities, and were selected from the ranks of teachers, graduate and post graduate students, health care providers, health services managers and researchers. The Colloquium was intended to encompass both the diversity of the national context and the international developments.

Four main thematic areas were in focus during the colloquium: (1) The role of IPE and practice in promoting equity in health, a national priority due to the burden of inequality still prevalent; (2) Interprofessional educational and practice in the public policies for reorienting health professional training in Brazil, with an emphasis in the effects of the "nudging function" of the Ministry of Health in the present context; (3) The need for more evidence coming from research on IPE and interprofessional practice (IPP), that may show impacts on quality both in the educational and the service delivery processes; (4) A critical look on the pioneering experiences on IPE and IPP and their interactions with a wider intersectoral perspective.

Several of the IPE experiences analyzed were considered as wide-range innovations in the federal universities. In Unifesp's campus Baixada Santista, in 2006 an integrated interprofessional curriculum was put in practice, with the participation of six health professional courses, and guided by IPE, teamwork promotion and collaborative practice; the Ceilandia School of Health (FC), part of the Federal University of Brasilia (UnB), from its inception in 2008, was composed of five professional courses that develop activities in an integrated fashion and interacts with a local community that was requesting access to higher education; the Federal University of the South Bahia (UFSB) chartered in 2013 adopted from the start a cycle structure in order to allow for a greater flexibility to design higher education itineraries beginning with an Interdisciplinary Bachelor in Health Sciences to progress, depending on the student's choice, to a more traditional health professions career and post graduate studies. All these initiatives were considered as examples of shifts in the model, and are especially relevant considering the present expansion of universities and health care professional courses in countryside and mid-size cities and regarding the public policies geared to strengthen the primary care based healthcare model.

Discussions at the colloquium also stressed the importance of several "nudging policies" for reorientation of health professional education emanated from the partnership Ministry of Health- Ministry of Education: the Training though Work in Health (PET-Saude) and the Multi-professional Residency Program. The former is a strategy to promote training-service-community integration, gathering teachers and students of different fields and practitioners. It places a bet in the role of working in the primary care setting as a tool for the improvement of the learning process, and specifically promoting the students' integration in the Family Health Strategy. In this way, PET-Saude can be considered the main locus for integration of activities between healthcare and health professional training. 
An overview of IPE in Brazil in a recent article that mapped out initiatives in the global context, including Latin America ${ }^{2}$, presented a series of still not consolidated experiences, scattered around the Brazilian territory in diverse geographic and social settings. A strong point made by the colloquium was that there is a need to systemize the range of experiences that are being developed throughout Brazil. It was also stressed the importance of disseminating all that is being produced as food for thoughts and critical reflection on these IPE implementation scenarios, to add up forces to overcome barriers and to claim for the continuity of robust public policies.

\section{Establishing a national interprofessional network}

As a result of the colloquium, a set of actions and priority areas demanding for investments in order to strengthen IPE in Brazil were listed: to promote local and regional core groups to mobilize forces around IPE from universities to support and consolidate the existing initiatives; to request the continuity of the nudging policies of the Ministry of Health-Ministry of Education such as PET-Saude and Multiprofessional Residency; to build a collaborative network in interprofessional education and practice, allowing information exchange, reciprocal learning and support for the expansion of IPE and collaborative practice in the country; to promote a network of medical schools that may foster innovations and an expanded dialogue with other health professional schools; to engage in dialogues and collaboration with the international community of stakeholders interested in IPE; to develop research to supply evidences about different aspects of implementation of IPE in Brazil, evaluating its effects in quality of both training process and healthcare services, contributing to build a shared base of concepts and terminology.

\section{Concluding comments}

The road ahead in Brazil looks extensive, and progress will require not only dialogues but an effective alliance among all those with a stake in the improvement of healthcare and professional training - universities, health professionals, managers and decision-makers in all levels of government, public regulation agencies, patients and population. This joint movement may prove itself useful to overpass hegemonic models of single and separated professional training and practice that are not longer responsive to present challenges and complexities of health needs.

Ana Maria Chagas Sette Câmara

Departamento de Fisioterapia, Universidade Federal de Minas Gerais. Belo Horizonte, MG, Brazil. anasettecamara@gmail.com

Antonio Pithon Cyrino

Faculdade de Medicina de Botucatu, UNESP - Univ Estadual Paulista. Botucatu, SP, Brazil. acyrino@fmb.unesp.br

Eliana Goldfarb Cyrino

Faculdade de Medicina de Botucatu, UNESP - Univ Estadual Paulista. Botucatu, SP, Brazil. ecyrino@fmb.unesp.br 
George Dantas Azevedo

Escola Multicampi de Ciências Médicas, Universidade Federal do Rio Grande do Norte. Natal, RN, Brasil. georgedantas.faimer@gmail.com

Marcelo Viana da Costa Departamento de Enfermagem, Universidade do Estado do Rio Grande do Norte. Pau dos Ferros, RN, Brasil. vianacostam@yahoo.com.br

Maria Isabel Barros Bellini Faculdade de Serviço Social, Pontifícia Universidade Católica do Rio Grande do Sul. Porto Alegre, RS, Brasil. maria.bellini@pucrs.br

Marina Peduzzi Escola de Enfermagem, Universidade de São Paulo. São Paulo, SP, Brasil. marinape@usp.br

Nildo Alves Batista

Centro de Desenvolvimento do Ensino Superior em Saúde, Universidade Federal de São Paulo (Unifesp). campus Baixada Santista. Santos, SP, Brasil.nbatista@unifesp.br

Sylvia Helena Souza da Silva Batista Departamento Saúde, Educação e Sociedade, Unifesp, campus Baixada Santista. Santos, SP, Brasil.sylvia.batista@unifesp.br

Scott Reeves Centre for Health and Social Care Research, Kingston University; St George's University of London. London, UK. s.reeves@sgul.kingston.ac.uk

\section{References}

1. Costa MV, Vilar MJ, Azevedo GD, Reeves S. Interprofessional education as an approach for reforming health professions education in Brazil: emerging findings. J Interprof Care. 2014; 28(4):379-80.

2. Barr H. Interprofessional education: the genesis of a global movement. London: Centre for Advancement of Interprofessional Education; 2015.

3. Ministério da Saúde. Política Nacional de Atenção Básica [Internet]. [acesso 2015 Set 14]. Ministério da Saúde: Brasília (DF): MS; 2012. Disponível em: http://189.28.128.100/ dab/docs/publicacoes/geral/pnab.pdf

4. Lei $n^{\circ} 8.080$, de 19 de setembro de 1990. Dispõe sobre as condições para a promoção, proteção e recuperação da saúde, a organização e o funcionamento dos serviços correspondentes e dá outras providências. Diário Oficial da união. 19 Set 1990. 128(182).

5. Furtado JP. Equipes de referência: arranjo institucional para potencializar a colaboração entre disciplinas e profissões. Interface (Botucatu). 2007; 11(22):239-55.

6. World Health Organization. Framework for action on interprofessional education \& collaborative oractice. Geneva: WHO; 2010. 